\title{
Assessment of In-Situ Natural Dendroremediation Capability of Rhizophora racemosa in a Heavy Metal Polluted Mangrove Forest, Rivers State, Nigeria
}

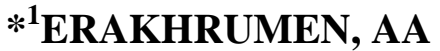 \\ Department of Forest Resources \& Wildlife Management, Faculty of Agriculture, \\ University of Benin, Benin City, Nigeria \\ Phone: +234-803-384-0510; Email Address: erakhrumen@yahoo.com
}

KEY WORDS: Mangrove forest, Coastal pollution, Noxious substances, Toxic metals, Phytoremediation

\begin{abstract}
Environmental pollution is assuming frightening dimensions in many parts of the world. This is not excluding Niger-Delta region of Nigeria where most of the country's oil and gas are sourced with attendant production of noxious substances as byproducts/residues/waste. Many of these noxious substances have been noted to be removable from polluted environment through proper application of phytoremediation techniques, particularly using native plant species. Consequently, this research was conceived to evaluate potentials for phytomediation by native red mangrove tree (Rhizophora racemosa G.F.W. Meyer). This was carried out by evaluating the presence of heavy metals ions and their bioconcentration levels in the samples of root and wood tissues axially along the stem of this tree. The sorrounding soil and water were also sampled and evaluated for presence and concentration of these metal ions in comparison with those for the sampled plant tissues. All the samples were sourced from a mangrove forest in Okrika, Rivers State, Nigeria. The samples from the root, butt, $50 \%$ and $90 \%$ bole length were oven-dried at $60 \pm 5^{\circ} \mathrm{C}$ to constant weight, pulverised and heated with trioxonitrate (v) acid to achieve total dissolution before subjecting them to atomic absorption spectroscopy (AAS). Similarly, samples from sorrouding soil were dried at $35 \pm 2^{\circ} \mathrm{C}$ to constant weight, crushed and sieved using a $\leq 2 \mathrm{~mm}$ mesh before performing metal extraction and detection using AAS while water samples were also subjected to AAS for heavy metal analyses, in line with appropriate standard methods. The data obtained were statistically analysed using basic descriptive tools, Analyses of Variance and Fishers' Least Significant Difference $(P<0.05)$. Outcomes of these statistical analyses showed that, in terms of bio-concentration values, the evaluated metal ions that include $\mathrm{Fe}, \mathrm{Cu}, \mathrm{Mn}, \mathrm{Cd}, \mathrm{Pb}, \mathrm{Ni}$ and $\mathrm{Cr}$ were more in the root than the surrounding soil and water. The bio-concentration trends, for the metal ions, also progressively declined from the root towards the crown of the trees. The bio-concentration distribution in all the tree sections showed an inconsistent pattern with Fe ions having higher bio-concentration. In addition, $\mathrm{Cr}$, $\mathrm{Ni}, \mathrm{Pd}$ and $\mathrm{Cu}$ also inconsistently followed $\mathrm{Fe}$ in terms of bio-concentration level. C JASEM
\end{abstract}

\section{http://dx.doi.org/10.4314/jasem.v19i1.3}

\section{Introduction}

Literature have it that many countries, especially those in the developing region, have witnessed significant environmental pollution in recent times owing to the interplay of demographic and socioeconomic forces, among other reasons. The case of Nigeria, particularly its Niger-Delta region, is not different. Pollution in this part of the country have been worsened by the various activities revolving round the exploration for and exploitation of crude oil and gas including poor regulation of these activities (Erakhrumen, 2007). The interplay of these activities include all that relate to the location of crude oil and gas deposit using geological mapping and seismic surveys, drilling of the oil wells and its development to production level (Levorsen, 1967).
These activities have series and varying impacts on the environment, with the most significantly negative ones being the release of pollutants in the form of residues/by-products/wastes containing toxic substances such as hydrocarbons and heavy metals into the environment in concentrations not naturally found in such places. Environmental pollution by heavy metals is of importance owing to their nonbiodegradability, accumulative capabilities and toxicity to life-forms (Purves, 1985; Henry, 2000; Ghosh and Singh, 2005; Neff et al., 2006; Erakhrumen, 2012; Erakhrumen, 2014). Therefore, since metals cannot be degraded, unlike organic compounds, clean-up usually requires their removal from polluted medium (Ghosh and Singh, 2005).

Studies aimed at physico-chemical methods, such as chemical precipitation, chemical oxidation or 
reduction, electrochemical treatment, evaporative recovery, filtration, ion exchange, membrane technologies, among others, have been carried out in order to remove heavy metal ions from some types of effluents and industrial wastewater. These methods may sometimes be effective, however, they are not only expensive most times, but may also be uneconomical especially when the heavy metal ions are present at low concentration levels (Volesky, 1990; Erakhrumen, 2011). This cconcern has led to calls for other simple, cheaper and environmetallyfriendly approaches that are easily acceptable, adoptable and adaptable by most stakeholders.

One of such alternative approaches is the application of bioremediation, i.e., the utilisation of diverse collection of naturally occurring or geneticallyengineered vascular plants, algae, fungi, among others, to control, breakdown, and/or remove wastes/toxic substances, or to encourage degradation of contaminants in the rhizosphere, or root region of the plant (Cunningham et al., 1997; Flathman and Lanza, 1998; McCutcheon and Schnoor, 2003). Phytoremediation, an important bioremediation technique, may not yet be a commercially available technology in many parts of the world including Nigeria (Erakhrumen, 2007), however, the ability of certain plants, such as mangrove species, to develop ecosystems with adaptation to exist in polluted and/or hostile environment is worth being investigated for beneficial applications.

This is so because little is still known, for instance, about in-situ control and/or removal of heavy metals from polluted medium by mangrove plants (Pahalawattaarachchi et al., 2009; Nirmal Kumar et al., 2011; Erakhrumen, 2014). The inadequate information in this regard is irrespective of the several studies on heavy metal contamination in mangrove soils, sediments and water including their negative effects on organisms (Seng et al., 1987; Ismail and Asmah, 1992). In line with the foregoing, this research was carried out to evaluate the potentials for bioremediation of heavy metal contaminated soil and water through the process of in-situ phytoremediation by a mangrove woody species commonly known and referred to as Red mangrove. This woody species scientifically known as Rhizophora racemosa G.F.W. Meyer is native to the coastline of Niger-Delta region.

\section{MATERIALS AND METHODS}

Brief description of the study area: The Niger-Delta coast extends from the mouth of the Benin River, in the west, for about 500 kilometers to the mouth of the Imo river in the east. The delta is arcuate in plan-form and is rimmed by a chain of sandy barrier islands approximately 2000 square kilometers in area (Ajao et al., 1996). This delta in the Nigerian coastal zone experiences a tropical climate consisting of a rainy season (April to October) and a dry season (November to March). Diurnal temperature is high reaching $34^{\circ} \mathrm{C}$ to $35^{\circ} \mathrm{C}$. Relative humidity is high throughout the year and is rarely below $60 \%$. High rainfall of between $3000 \mathrm{~mm}$ and $4000 \mathrm{~mm}$ is experienced during the months of May to September with a short dry break in August.

The specific location where samples from the trees, soil and water were sourced in August, 2011, for the experiments in this research, was a mangrove forest within the area observed to be presently impacted by pollution from crude oil exploration and exploitation activities in Okrika (Longitude $7^{\circ} 04^{\prime} \mathrm{E} \&$ Latitude $4^{\circ}$ $44^{\prime} \mathrm{N}$ ) in Rivers State, Nigeria. Okrika is a port town in the Niger-Delta region, situated south of Port Harcourt, Rivers State, Nigeria. The average elevation is 452 metres and lies north of the Bonny River and on Okrika Island. Close to this town is the Alesa-Eleme oil refinery with pipelines built to a jetty on Okrika Island. Okrika town also has a major gas plant facility (Alakiri gas plant) that supplies to the refinery and others.

Sampling procedure: Five $R$. racemosa trees of similar diameter at breast height were felled. Samples from their submerged root tissues were obtained from each of the felled tree, carefully rinsed with distilled water and placed separately into five properly labelled chemically clean polythene bags ensuring that they are protected from external contamination and transferred to the laboratory, in ice boxes, for subsequent analyses of presence and bioconcentration of heavy metals.

After the removal of the branches and crown, samples were also taken from these felled trees by sectioning the stems into three bolts i.e., butt, $50 \%$ and $90 \%$ bole length. A middle piece section was obtained from each bolt, properly labelled and transferred into chemically clean polythene bags and subsequently moved, in ice boxes, to the laboratory where they were homogenised. This sampling procedure was adopted in order to evaluate the presence and bioconcentration variability of heavy metals along the stem of the sampled mangrove trees.

Soil samples were obtained close to the felled trees at a depth of $50 \mathrm{~cm}$ in such a way that introduction of plant matter was avoided. Samples of $0.5 \mathrm{~kg}$ each were collected close to each felled tree, making a total of five samples, collected at the site using a clean stainless steel scoop and kept differently in five properly labelled polypropylene containers that were carefully sealed to avoid contamination. They were transferred to the laboratory, in ice boxes, and stored at a temperature of $4^{\circ} \mathrm{C}$ to prevent microbial activity that could modify their properties. 
Water samples were collected close to the harvested trees using sterile containers, filtered through 0.45 $\mu \mathrm{m}$ filters into 1-litre chemically clean amber glass bottles, acidified with few drops of trioxonitrate (v) acid $\left(\mathrm{HNO}_{3}\right)$ and covered with Teflon-lined lids completely protecting the samples from any external contamination. The bottles containing the samples were also properly labelled and transferred to the laboratory, in ice boxes, for heavy metal analyses.

\section{Laboratory analyses}

Root and Stem samples: Atomic absorption spectroscopy technique was applied in analysing and quantifying the types of heavy metals in the sampled root and stem wood. Perkin-Elmer 30303B Atomic Absorption Spectrophotometer (AAS) was used for the analyses. Samples of root and stem wood obtained from the different sections along the boles of the felled trees were carefully oven-dried at $60 \pm 5^{\circ} \mathrm{C}$ in the laboratory to constant weight, broken down separately into pieces, pulverised to fine powder, in an even mix, using a Hammer Mill crusher, making sure external contaminations were avoided and subsequently kept separately in desiccators.

The pulverised samples were sieved to assist in dissolution since samples were to be analysed in solution form. A $0.5 \mathrm{~g}$ of each pulverised and sieved sample from the different sections (i.e., root, butt, $50 \%$ and $90 \%$ bole length) of the sampled trees were measured into a chemically clean beaker successively in ten replications. A $10 \mathrm{ml}$ volume of concentrated $\mathrm{HNO}_{3}$ was added to each of the ten experimental samples and heated until total dissolution was attained, washed with deionised water into a standard $50 \mathrm{ml}$ volumetric flask and analysed for heavy metals in line with the method described by Perkin-Elmer Corporation, (1996).

Soil samples: The soil samples were first dried in an electric oven at a temperature of $35 \pm 2^{\circ} \mathrm{C}$ until their weight became constant. They were homogenised after being crushed and sieved using stainless steel sieves of size $\leq 2 \mathrm{~mm}$ mesh. The extractions were performed on fractions of size $\leq 2 \mathrm{~mm}$ to ensure homogeneity of the samples. Large soil particles were removed. Sequential metals extraction methods were adopted with subsequent metal detection using Perkin-Elmer 30303B AAS, both in conformity with the appropriate standard method described by PerkinElmer Corporation, (1996).

Water samples: Samples of water were analysed for presence, types and concentration levels of heavy metals using Perkin-Elmer 30303B AAS in conformity with the appropriate standard method described by Perkin-Elmer Corporation, (1996).
Statistical Analyses: The data obtained for the bioconcentrations values of heavy metals in the root and along the boles of the $R$. racemosa trees and those obtained for soil and water samples were statistically described using basic tools. In addition, analyses of variance (ANOVA), was employed in analysing the data for statistical significant variation $(P<0.05)$ while Fishers' Least Significant Difference (LSD) was applied for separation of significantly different means $(P<0.05)$.

\section{RESULTS AND DISCUSSION}

The outcomes of statistical analyses done on the data from the experiments conducted to evaluate the heavy metal content of samples from root and wood along the stem of $R$. racemosa trees including samples from soil and water surrounding the harvested trees are tabulated in Table 1 . The results revealed presence and variable concentrations of some heavy metals, such as $\mathrm{Fe}, \mathrm{Cu}, \mathrm{Mn}, \mathrm{Cd}, \mathrm{Pb}, \mathrm{Ni}$ and $\mathrm{Cr}$ ions, in all the plant tissues, soil and water samples that were evaluated. It was observed that the mean bioconcentration levels, in $\mathrm{mgkg}^{-1}$, of all the metals were higher in the root (Fe: 1641.36, $\mathrm{Cu}: 421.59, \mathrm{Mn}$ : 330.03, Cd: 343.08, Pb: 502.04, Ni: 609.59 and $\mathrm{Cr}$ : 630.11) than in the surrounding soil (Fe: $58.75, \mathrm{Cu}$ : 25.97, Mn: 23.30, Cd: 28.10, Pb: 41.53, Ni: 33.85 and $\mathrm{Cr}: 20.97)$ and water, in mglitre ${ }^{-1},(\mathrm{Fe}: 21.95, \mathrm{Cu}$ : 14.70, Mn: 16.23, Cd: 19.61, Pb: 27.49, Ni: 28.08 and $\mathrm{Cr}$ : 14.80). It was also observed from the results that mean bio-concentration levels of the heavy metals were more in the root than other evaluated above-ground parts of the stem.

Similarly, all the heavy metals ions declined in bioconcentration levels from the root towards the crown in all the trees. The bio-concentration levels for all the heavy metals (Table 1), declined from the root towards the butt, they declined further towards the middle of the sampled tree (50\% bole length) and had lowest bio-concentration levels towards the crown of the trees ( $90 \%$ bole length). Furthermore, the results of ANOVA (Table 2) showed a statistical significant variation in pooled data for bio-concentrations of all the heavy metals that were evaluated in the root, at the various sections along the stem, including their concentrations in soil and water. In separating the means, Fisher's LSD (Table 1) revealed that the mean values obtained for the data on bio-concentrations of all the heavy metals for samples from the root, those along the stem and their concentration in the soil and water were all significantly different from each other.

Plant species that are recommended for use in phytoremediation of metal contaminated media are those with inherent and/or assisted adaptive biological mechanisms, such as those related to avoidance/exclusion and/or tolerance/accumulation, that assist them in resisting or tolerating higher bioconcentrations of metal ions in their tissues (Ashraf et 
al., 2011; Erakhrumen, 2012), among other mechanisms. Metal accumulating plants, in most instances, are those capable of having bioconcentration levels of the pollutants in their tissues above that of the contaminated media (Erakhrumen, 2012; Erakhrumen, 2014). The results showed that the bio-concentrations of all the heavy metal ions evaluated were higher in the root and above-ground parts than the surrounding soil and water in bioconcentration levels that suggest this tree as a probable hyperaccumulator.

Studies such as Nazli and Hashim, (2010), Nirmal Kumar et al., (2011), Usman et al., (2013), Almahasheer et al., (2014) and Erakhrumen, (2014) reported similar results concerning higher bioconcentration of heavy metal ions in root and some above-ground parts as compared to surrounding soil or sediments and water as those obtained in this study. Based on this result, this tree species appears to possess the property described as hyperaccumulation, known for those kinds of vascular plants that have the capacity for extreme metal absorption and accumulation in parts of their tissues. These kinds of plants are simply referred to as hyperaccumulators, because they accumulate appreciable quantities of metal in parts of their tissues regardless of the concentration of metal in the soil, water or other surrounding contaminated media (Prasad and 2003).

Table 1: Heavy metal constituents and their bio-concentration levels in the root and stem wood from $R$. racemosa, soil and surrounding water in a mangrove forest, Rivers State, Nigeria

\begin{tabular}{|c|c|c|c|c|c|c|c|}
\hline Source of & \multicolumn{7}{|c|}{ Types of heavy metal constituents and their bio-concentration levels including SD values and LSD results } \\
\hline test samples & $\mathrm{Fe}$ & $\mathrm{Cu}$ & $M n$ & $C d$ & $\mathrm{~Pb}$ & $\mathrm{Ni}$ & $\mathrm{Cr}$ \\
\hline $\operatorname{Root}\left(\mathrm{mgkg}^{-1}\right)$ & $1641.36^{\mathrm{a}} \pm 1.69$ & $421.59^{\mathrm{a}} \pm 0.67$ & $330.03^{\mathrm{a}} \pm 1.49$ & $343.08^{\mathrm{a}} \pm 1.18$ & $502.04^{\mathrm{a}} \pm 0.18$ & $609.59^{\mathrm{a}} \pm 0.34$ & $630.11^{\mathrm{a}} \pm$ \\
\hline Butt $\left(\mathrm{mgkg}^{-1}\right)$ & $612.78^{\mathrm{b}} \pm 1.15$ & $105.74^{\mathrm{b}} \pm 0.57$ & $154.98^{\mathrm{b}} \pm 0.76$ & $101.92^{\mathrm{b}} \pm 0.45$ & $260.19^{\mathrm{b}} \pm 0.32$ & $210.12^{\mathrm{b}} \pm 0.34$ & $110.14^{\mathrm{b}} \pm 0.35$ \\
\hline Bole length $\left(\mathrm{mgkg}^{-1}\right)$ & $189.75^{\mathrm{c}} \pm 0.87$ & $87.91^{\mathrm{c}} \pm 0.54$ & $51.62^{\mathrm{c}} \pm 0.70$ & $71.41^{\mathrm{c}} \pm 1.04$ & $94.81^{\mathrm{c}} \pm 0.13$ & $88.52^{\mathrm{c}} \pm 0.35$ & $41.30^{\mathrm{c}} \pm 0.41$ \\
\hline Bole length $\left(\mathrm{mgkg}^{-1}\right)$ & $60.79^{d} \pm 0.66$ & $54.14^{\mathrm{d}} \pm 0.57$ & $22.00^{\mathrm{d}} \pm 0.38$ & $33.31^{\mathrm{d}} \pm 0.61$ & $43.02^{\mathrm{d}} \pm 0.12$ & $39.07^{\mathrm{d}} \pm 0.10$ & $22.48^{\mathrm{d}} \pm 0.31$ \\
\hline Soil $\left(\mathrm{mgkg}^{-1}\right)$ & $58.75^{\mathrm{e}} \pm 0.33$ & $25.97^{\mathrm{e}} \pm 0.06$ & $23.30^{\mathrm{e}} \pm 0.05$ & $28.10^{\mathrm{e}} \pm 0.02$ & $41.53^{\mathrm{e}} \pm 0.04$ & $33.85^{\mathrm{e}} \pm 0.04$ & $20.97^{\mathrm{e}} \pm 0.04$ \\
\hline Nater $\left(\right.$ mglitre $\left.^{-1}\right)$ & $21.95^{\mathrm{f}} \pm 0.06$ & $14.70^{\mathrm{f}} \pm 0.02$ & $16.23^{\mathrm{f}} \pm 0.03$ & $19.61^{\mathrm{f}} \pm 0.02$ & $27.49^{f} \pm 0.03$ & $28.08^{\mathrm{f}} \pm 1.27$ & $14.80^{\mathrm{f}} \pm 0.02$ \\
\hline
\end{tabular}

Each mean value is the overall mean of ten experimental replications per tree

Means with the different superscripts in the same column are significantly different $(\mathrm{p}<0.05)$

Table 2: Summary of ANOVA results for data obtained for the heavy metals bio-concentration levels in the sampled root and along the stem

\begin{tabular}{cccc}
\hline Source of variation & $\begin{array}{c}\text { Heavy metal } \\
\text { Content }\end{array}$ & $($ F-cal $)$ & $(F-t a b)$ \\
& $F e$ & $4357019^{*}$ & \\
& $C u$ & $997612^{*}$ & \\
Data sampling from root and & $M n$ & $268673^{*}$ & \\
sections along the stem of trees & $C d$ & $300283^{*}$ & 4.43 \\
& $\mathrm{~Pb}$ & $1.277 \mathrm{E} 7 *$ & \\
& $\mathrm{Ni}$ & $1565919^{*}$ & \\
& $\mathrm{Cr}$ & $8311725^{*}$ & \\
\hline
\end{tabular}

Furthermore, similar observations from studies on some mangrove species where root had more heavy metals bio-concentration in comparison to the stem and other above-ground parts have also been made for Avicennia alba (Thomas and Ferdinandez, 1997), Rhizophora mucronata (Pahalawattaarachchi et al., 2009), Avicennia marina (Nirmal Kumar et al., 2011), Bruguiera sexangula and Ceriops decandra (Gupta and Chakrabarti, 2013), Avicennia marina (Almahasheer et al., 2014), Phragmites australis in a wetland vegetation (Ahmad et al., 2014) and recently also in Rhizophora racemosa (Erakhrumen, 2014). This comparatively higher bio-concentration level of heavy metals in the root might be as a result of low mobility and bioavailability of some heavy metals to natural phytoextraction process (Komárek et al., 2007) along the stem towards the crown.
Reported studies have also shown that uptake of heavy metals by plants is passive and their translocation from root to other plant organs is quite low and slow (De Lacerda and Abrao, 1986; Baker and Walker, 1990; Wolterbeek and Van, 2002; Nirmal Kumar et al., 2008). Similar to these studies' outcomes are those of Tam et al., (1997), Sur et al., (2006) and Wei et al., (2008). In addition, other likely implication of this observation is that the root might be acting as a barrier for heavy metal translocation thereby protecting the sensitive parts of the plant (e.g. Gupta and Chakrabarti, 2013). Furthermore, as noted earlier by Erakhrumen, (2014), this might likely be one of the techniques utilised by this tree in removing toxic heavy metals from polluted medium.

The bio-concentration distributions of the evaluated heavy metals in the various sampled sections of the tree are in the order: Root: 
$\mathrm{Fe}>\mathrm{Cr}>\mathrm{Ni}>\mathrm{Pb}>\mathrm{Cu}>\mathrm{Cd}>\mathrm{Mn}$; Butt:

$\mathrm{Fe}>\mathrm{Pb}>\mathrm{Ni}>\mathrm{Mn}>\mathrm{Cr}>\mathrm{Cu}>\mathrm{Cd} ; 50 \%$ bole length:

$\mathrm{Fe}>\mathrm{Pb}>\mathrm{Ni}>\mathrm{Cu}>\mathrm{Cd}>\mathrm{Mn}>\mathrm{Cr} ; 90 \%$ bole length:

$\mathrm{Fe}>\mathrm{Cu}>\mathrm{Pb}>\mathrm{Ni}>\mathrm{Cd}>\mathrm{Cr}>\mathrm{Mn}$. This trend may

ordinarily appear inconsistent, however, observations of somewhat similar trends in literature such as $\mathrm{Zn}>\mathrm{Pb}>\mathrm{Cr}>\mathrm{Cu}>\mathrm{Cd}$ (Ramos and Geraldo, 2007) and $\mathrm{Pb}>\mathrm{Zn}>\mathrm{Cd}$ (Nirmal Kumar et al., 2011) had been earlier made in some mangrove species. In another study by Pahalawattaarachchi et al., (2009), it was found that the mobility of metals from the root to leaves in $R$. mucronata was in the order $\mathrm{Zn}>\mathrm{Ni}=\mathrm{Cr}>\mathrm{Fe}>\mathrm{Pb}>\mathrm{Cu}$.

The bio-concentration distribution trend highlighted earlier showed that the level of $\mathrm{Fe}$ ions was comparatively higher than other heavy metals in the root and other sections of the stem. That is, Fe ion had higher bio-concentration levels than other heavy metals ions in the root, butt, $50 \%$ and $90 \%$ bole length. The heavy metals bio-concentration distribution in the root showed that the bioconcentration level of $\mathrm{Fe}$ ions was higher followed by those of $\mathrm{Cr}$ and $\mathrm{Ni}$ respectively. Furthermore, in terms of bio-concentration levels, both the butt and $50 \%$ bole length had $\mathrm{Fe}$ ions being followed by $\mathrm{Pb}$ and $\mathrm{Ni}$ ions respectively while at $90 \%$ bole length $\mathrm{Fe}$ ion was followed by $\mathrm{Cu}$ and $\mathrm{Pb}$ ions respectively in terms of bio-concentration levels.

Irrespective of the inconsistent trends, the bioconcentration distribution indicate that this woody species ( $R$. racemosa) showed the potentials of having the capability of taking up heavy metal ions from its surrounding soil and water with most of them being concentrated or accumulated in the root. The likely implication of this observation is that this species may have the potential capability for in-situ phytoremediation through the process known as hyperaccumulation noted for phytoextraction. It will therefore be necessary to establish and document the favourable conditions that enhance the techniques employed by this tree species in achieving this purpose. Information is presently limited concerning the use of $R$. racemosa for phytoremediation or dendroremediation (Erakhrumen,, 2014).

However, it is noteworthy that some studies have earlier shown that mangrove can be used as a tertiary wastewater treatment (Twilley, 1998). Similarly, reports have also shown that mangrove species like Avicenia marina can be utilised in removing certain metals, such as zinc contamination, from polluted sites (Macfarlane and Burchett, 1999). Therefore, since Rhizophoraceae dominate most tropical mangroves, and are generally believed to play a vital role in maintaining mangrove ecosystems including shoreline protection, support of estuarine and marine food chains and enhancement of water quality in near-shore environments including coral reef areas
(Duke and Allen, 2006), it will be necessary to investigate and maximise this phytoremediation potential in these trees that also have capability for high biomass production.

The results of statistical analyses conducted by subjecting the pooled data obtained for bioconcentration of each heavy metal in the root, along the stem, in surrounding soil and water to ANOVA at $5 \%$ probability level (Table 2 ) showed that there was statistically significant variation in the data obtained for bio-concentration levels of all the heavy metals ions from the root and along the stem of the trees including the soil and water. This implies that these heavy metals' bio-concentration in the root and their translocation along the stem is not likely to be uniform for reasons beyond the scope of this study. Nevertheless, the results of Fisher's LSD of pair of means for the evaluated data (Table 1) showed that there was statistically significant difference in the bio-concentration values for all the heavy metals that were evaluated among the root, all the sections along the trees including soil and water.

Conclusion: The claims that mangrove species contribute to in-situ remediation of polluted sites coupled with water quality enhancement are still with inadequate published data in the tropical region. Rhizophoraceae are dominant in tropical mangrove forests, making them a potential perennial woody species for dendroremediation particularly in polluted coastal parts of the tropics. The results obtained from this research aimed at heavy metal analyses of root and stem wood from $R$. racemosa including soil and water samples sourced from a polluted site corroborate the claims earlier highlighted. However, more studies that will contribute to efforts at maximising the observed capability for in-situ phytoremediation by this species will be necessary.

Acknowledgement: The author acknowledges the funding support for, and permission to publish scientific articles from an International Foundation for Science (IFS) funded study entitled "Evaluation of Dendroremediation Capability of Nigerian Red Mangrove (Rhizophora racemosa G.F.W. Meyer) in the Niger-Delta Region" through the IFS Grant W/4505-1, from Stockholm, Sweden.

\section{REFERENCES}

Ahmad, S.S., Reshi, Z.A., Shah, M.A., Rashid, I., Ara, R. and Andrabi, S.M.A. (2014): Phytoremediation Potential of Phragmites australis in Hokersar Wetland - A Ramsar Site of Kashmir Himalaya. International Journal of Phytoremediation, 16(12): 1183-1191.

Ajao, E.A., Oyewo, E.O. and Unyimadu, J.P. (1996): A Review of the Pollution of Coastal Waters in Nigeria. Nigerian Institute for Oceanography and 
Marine Research (NIOMR) Technical Paper No. 107 of March, 1996. ISBN-978-2345-113. 20 pages.

Almahasheer, H.B., Al-Taisan, W.A. and Mohamed, M.K. (2014): Metals Accumulation in Grey Mangrove (Avicennia marina (Forsk.) Vierh.) Inhabiting Tarut Bay, Eastern Saudi Arabia. Journal of Agricultural Science, 6(1): 137-149.

Ashraf, M.A., Maah, M.J. and Yusoff, I. (2011): Heavy Metals Accumulation in Plants Growing in Ex Tin Mining Catchment. International Journal of Environmental Science \& Technology, 8(2): 401-416.

Baker, A.J. and Walker, P.I. (1990): Ecophysiology of Metal Uptake by Tolerant Plants. In: Shaw, A.J. (Ed.) Heavy Metal Tolerance in Plants Evolutionary Aspects. Boca Raton, FL.: CRC, Press. pp. 155-178.

Cunningham, S.D., Shann, J.R., Crowley, D.E. and Anderson, T.A. (1997): Phytoremediation of Contaminated Water and Soil. In: Kruger, E.L., Anderson, T.A. and Coats, J.R. (Eds.) Phytoremediation of Soil and Water Contaminants. Washington, DC: American Chemical Society. ACS Symposium Series 664. pp. 2-19.

De Lacerda, L.D. and Abrao, J.J. (1986): Heavy Metal Accumulation by Mangrove and Salt Marsh Intertidal Sediments. Marine Pollution Bulletin, 17: 246-250.

Duke, N.C. and Allen, J.A. (2006): Rhizophora mangle, $R$. samoensis, $R$. racemosa, $R . \quad \times$ harrisonii (Atlantic-East Pacific Red Mangrove): Rhizophoraceae (mangrove family). In: Species Profiles for Pacific Island Agroforestry. 18pp. Available at: www.traditionaltree.org

Erakhrumen, A.A. (2007): Phytoremediation: An Environmentally Sound Technology for Pollution Prevention, Control and Remediation in Developing Countries. Educational Research and Review, 2(7): 151-156.

Erakhrumen, A.A. (2011): Research Advances in Bioremediation of Soils and Groundwater Using Plant-Based Systems: A Case for Enlarging and Updating Information and Knowledge in Environmental Pollution Management in Developing Countries. In: Khan, M.S., Zaidi, A., Goel, R. and Musarrat, J. (Eds.) Biomanagement of Metal-Contaminated Soils. Springer's Environmental Pollution Series 20: 143-166.
Erakhrumen, A.A. (2012): Studies on Phytoextraction Processes and Some Plants' Reactions to Uptake and Hyperaccumulation of Substances. In: Anjum, N.A., Pereira, M.E., Ahmad, I., Duarte, A.C., Umar, S. and Khan, N.A. (Eds.) Phytotechnologies: Remediation of Environmental Contaminants. Taylor \& Francis. pp. 521-540.

Erakhrumen, A.A. (2014): Potentials of Rhizophora racemosa for Bio-Indication and Dendroremediation of Heavy Metal Contamination in a Mangrove Forest, Ondo State, Nigeria. Nigerian Journal of Agriculture, Food and Environment, 10(4): 1-5.

Flathman, P.E. and Lanza, G.R. (1998): Phytoremediation: Current Views on an Emerging Green Technology. Journal of Soil Contamination, 7(4): 415-432.

Ghosh, M. and Singh, S.P. (2005): A Review on Phytoremediation of Heavy Metals and Utilization of its By-Products. Applied Ecology and Environmental Research, 3(1):1-18.

Gupta, S. and Chakrabarti, S.K. (2013): Mangroves- a Potential Phyto-Remediator and Useful BioIndicator against Heavy Metal Toxicity. International Journal of Bio-resource and Stress Management, 4(2) special: 322-327.

Henry, J.R. (2000): An Overview of Phytoremediation of Lead and Mercury. Washington, D.C: NNEMS Report. pp. 3-9.

Ismail, A. and Asmah, M.I.N. (1992): Copper, Zinc, Lead and Cadmium in Intertidal Molluscs and Sediment off Seberang Perai Coastline, Malaysia. 4th Princess Chulabhorn International Science Congress, Bangkok, Thailand.

Komárek, M., Tlustoš, P., Száková, J., Chrastný, V. and Balík, J. (2007): The Role of Fe- and Mnoxides during EDTA-Enhanced Phytoextraction of Heavy Metals. Plant, Soil and Environment, 53(5): 216-224.

Levorsen, A.F. (1967): Geology of Petroleum. Freeman \& Co. London, $2^{\text {nd }}$ Ed. p. 724.

McCutcheon, S.C. and Schnoor, J.L. (Eds.) (2003): Phytoremediation: Transformation and Control of Contaminants. Hoboken, NJ: WileyInterscience, Inc.

MacFarlane, G.R. and Burchett, M. (1999): Zinc Distribution and Excretion in the Leaves of the Grey Mangrove, Avicenia marina (Forsk.) Vierh. 
Environmental and Experimental Botany 41(2): $167-175$.

Nazli, M.F. and Hashim, N.R. (2010): Heavy Metal Concentrations in an Important Mangrove Species, Sonneratia Caseolaris, in Peninsular Malaysia. EnvironmentAsia, 3(1): 50-55.

Neff, J.M., Johnsen, S., Frost, T.K., Utvik, T.I.R. and Durell, G.S. (2006): Oil Well Produced Water Discharges to the North Sea. Part II: Comparison of Deployed Mussels (Mytilus edulis) and the DREAM Model to Predict Ecological Risk. Marine Environmental Research, 62: 224-246.

Nirmal Kumar, I.J., Sajish, P.R., Nirmal Kumar, R., Basil, G. and Shailendra, V. (2011): An Assessment of the Accumulation Potential of $\mathrm{Pb}$, $\mathrm{Zn}$ and Cd by Avicennia marina (Forssk.) Vierh. in Vamleshwar Mangroves, Gujarat, India. Notulae Scientia Biologicae, 3(1): 36-40.

Nirmal Kumar, J.I., Soni, H., Nimal Kumar, R. and Bhatt, I. (2008): Biomonitoring of Trace Elements in some Selected Aquatic Macrophytes with Reference to Lake Contamination: A Case Study of Pariyej Community Reserve, Gujarat, India. Asian Journal of Microbiology Biotechnology and Environmental Science, 10(4): 803-810.

Pahalawattaarachchi, V., Purushothaman, C.S. and Vennila, A. (2009): Metal Phytoremediation Potential of Rhizophora mucronata (Lam.). Indian Journal of Marine Sciences, 38(2): 178183

Perkin-Elmer Corporation, (1996): Analytical Methods for Atomic Absorption Spectroscopy. A Manual Published by Perkin-Elmer Corporation, US. 310pp.

Prasad, M.N.V. and Freitas, H.M. (2003): Metal Hyperaccumulation in Plants - Biodiversity Prospecting for Phytoremediation Technology. Electronic Journal of Biotechnology, 6(3): 285321.

Purves, D. (1985): Trace-Element Contamination of the Environment, 234 pp. Elsevier.

Ramos, G.M. and Geraldo, L.P. (2007): Assessment of Avicennia schaueriana, Laguncularia recemosa and Rhizophora mangle Plant Species as Bioindicator of Heavy Metal Pollution in Mangrove Environments. Engenharia-Sanitaria$e$-Ambiental, 12(4): 440-445.

Seng, C.E., Lim, P.P.E. and Ang, T.T. (1987): Heavy Metal Concentrations in Coastal Sea Water and
Sediment of Prai Industrial Estate, Penang, Malaysia. Marine Pollution Bulletin, 18: 611612.

Sur, P., Pandit, T.K., Naik, S.K., Mandal, M., Chakrabarty, A. and Das, D.K. (2006): Occurrence of Some Heavy Metals in Some Contaminated Soils and Crops of West Bengal. Indian Agriculture, 50(1-2): 79-84.

Tam, N.F.Y., Wong, Y. and Wong, Y.S. (1997): Accumulation and Distribution of Heavy Metals in a Stimulated Mangrove System Treated with Sewage. Asia-Pacific Conference on Science and Management of Coastal Environment. In: Proceedings of the International Conference, Hong Kong, 25-28 June, 1996. Hydrobologia, 352: $67-75$.

Thomas, G. and Ferdinandez, T.V. (1997): Incidence of Metals in the Mangrove Flora and Sediments in Kerala, India. Hydrobiologia, 352: 77-87.

Twilley, R.R. (1998): Mangrove Wetlands. In: Messina, M.G. and Conner, W.H. (Eds.) Southern Forested Wetlands. Ecology and Management. Boca Raton, Florida: Lewis Publishers. pp. 445 - 473.

Usman, A.R.A., Alkredaaa, R.S. and Al-Wabel, M.I. (2013): Heavy Metal Contamination in Sediments and Mangroves from the Coast of Red Sea: Avicennia marina as Potential Metal Bioaccumulator. Ecotoxicology and Environmental Safety, 97: 263-270.

Volesky, B. (1990): Removal and Recovery of Heavy Metals by Biosorption. In: Volesky B. (Ed.) Biosorption of Heavy Metals. Boca Raton: CRC Press. pp. 7-43.

Wei, L., Yan, C.L., Wu, G.R., Guo, X.Y. and Ye, B.B. (2008): Variation of Delta 13C in Aegiceras corniculatum Seedling Induced by Cadmium Application. Ecotoxicology, 17(6): 480-484.

Wolterbeek, H.T. and Van, M.A.J. (2002): Transport Rate of Arsenic, Cadmium, Copper and Zinc in Potamogeton pectinatus L.: Radiotracer Experiments with 76As, $109,115 \mathrm{Cd}, 64 \mathrm{Cu}$ and 65,69mZn. The Science of the Total Environment, 287: 1-2. http://dx.doi.org/10.1016/S0048-9697(01)009895 